\title{
Spatial Differentiation of Investment Attractiveness of Regions
}

\author{
Elena Lavrinenko \\ Department of Applied Economics and Economic Security \\ Belgorod State National Research University \\ Belgorod, Russia \\ lavrinenko_ea@mail.ru
}

\author{
Viktor Zakharov \\ Department of Social Technologies and Public Service \\ Belgorod State National Research University \\ Belgorod, Russia \\ zakharov@bsu.edu.ru
}

\begin{abstract}
The Russian Federation is characterized by interregional spatial differentiation of regions. The article analyzes the factors that affect the inflow of investment to the region. Methods for assessing the investment attractiveness of regions are described and an additional criterion is identified that allows increasing investment attractiveness and creating a positive investment climate in the region. As the main method for assessing the investment attractiveness of regions, it is assumed to use the expert method, which will allow evaluating not only quantitative, but also specific qualitative criteria. An additional criterion of investment attractiveness of regions is revealed. Increasing the investment attractiveness of the region directly depends on the availability of research and educational centers. These centers are able to identify priority areas for investors and provide staffing. The activities of scientific and educational centers are based on public and private partnership. The mechanism of public private partnership assumes that in order to reduce the spatial differentiation of investment attractiveness of regions, it is necessary to create a unified database of investment opportunities in the regions, indicating Federal and regional support tools and mechanisms, as well as information about promising enterprises. This database should include all sectors and branches of the economy of the Russian Federation. The article suggests a mechanism for interaction between the state, business and scientific and educational centers.
\end{abstract}

Keywords-investment attractiveness of regions, spatial differentiation, research and educational centers, public-private partnership, investment climate.

\section{INTRODUCTION}

In 2020, the spatial differentiation of regions is forming new structural and parametric contradictions. The growing spatial differentiation of regions causes sectoral and territorial redistribution of all types of resources, limiting the already modest investment potential of depressed regions, reducing the ability to independently determine regional development priorities, and increasing the regions, dependence on the Federal center and external forces. Positive regions of Russia have high investment potential, and state support for these regions actively contributes to this factor

The investment attractiveness of a region is determined by taking into account a set of factors that affect the feasibility, efficiency and risk level of investment. The concept of investment attractiveness of a region includes not only aspects of regulation and support of investment activities, but also fundamental factors that characterize the resource and infrastructure potential of Russian regions.

The region as an economic object has a dual character [1]. On the one hand, it is a relatively independent economic subsystem with its own resource and economic space, «on the other hand, the region (as a subject of the Federation) is a part of the national economy»[1,2], therefore, its functioning is associated with participation in the formation of a single economic space.

The spatial development of the Russian Federation is not only uneven, but also excessively concentrated in individual centers of economic activity, which leads to increased contrast «in the level of socio-economic development of regions» [2].

Territorial differentiation is based on the accumulated potential of territories, human, material, and financial resources, various risks, opportunities, and competitive advantages [3]. The balance of spatial development of regions characterizes the degree of dependence between the growth rate of investment in fixed assets and the dynamics of the gross regional product. Even 8-10 years ago, it was quite low. Today, this degree of dependence is increasing [4].

Solving the issue of attracting investment to the subjects of the Russian Federation requires regional authorities and management to take targeted actions to increase the investment attractiveness of territories within the framework of investment management in General [5].

Differentiation of regional development (a significant difference in the technological, social, economic, and environmental plan of a particular territory) determines the importance of investment attractiveness at the regional level, since there is an influx of "not only capital, but also technologies and managerial know-how that qualitatively change the economy of the recipient territory" [6].

This issue is resolved through regional policy (responsible bodies for policy implementation; creation of the necessary regulatory framework for the functioning of the investment market), scientific research, and the activities of regional development institutions. Improving investment attractiveness directly affects the development of investment activity and, in General, the intensity of investment activity in the country, region, and municipality by increasing the volume and pace of investment attraction.

The investment attractiveness of a region largely determines the speed and efficiency of its socio-economic development. «Investment attractiveness management at the regional level is 
complex: part of the legislation is the responsibility of the Russian Federation, and the other part is the joint responsibility of the Russian Federation and its subjects. In turn, the subjects of the Russian Federation can create their own programs and projects for the development of the territory» [7]

«The study of domestic and foreign scientific papers to identify factors and criteria for determining the investment attractiveness of regions allows us to conclude that there are a significant number of different typologies» [7]

Research and analysis of the investment attractiveness of the region at the present stage is quite difficult, since the existing classifications are quite difficult to correlate with each other. There is no clear understanding of the list of qualitative and quantitative indicators for assessing the investment attractiveness of the region.

The existing methods do not take into account many national projects [8,9] carried out by the government of the Russian Federation. Therefore, there is a need to adjust and Supplement the criteria for assessing the level of investment attractiveness of regions. New mechanisms are needed to increase the level of investment attractiveness of regions.

\section{METHODS}

Currently, the problems of assessing the level of investment attractiveness of the region are considered quite widely. There are many methods, each of which uses certain approaches to the formation of the structure of factors and assessment methods. The methods considered when writing the article include:

«The methodology of Council for study of productive forces of the Ministry of economic development of Russia and Russian Academy of Sciences (authors - I. Reisman, I. V. Grishina, A. G. Shahnazarov and others), according to which structural elements of investment climate in the region are investment potential, investment risk, investment attractiveness and activity» [10].

The methodology of «the Expert RA rating Agency consists in using two components of investment attractiveness of regions: investment potential and investment risk» [10].

«Method of factor analysis based on the construction of models: factor and regression» [11]. «Regression analysis focuses on identifying the weight of each factor attribute that affects the result, and quantifying the net impact of this factor. The emphasis in factor analysis is on the study of internal causes that form the specifics of the phenomenon under study, on the identification of generalized factors. Factor analysis does not require a priori division of features into dependent and independent ones» $[11,12]$. Considering the assessment of the level of investment attractiveness of the region, it is possible to use regression analysis (1):

\section{$\mathrm{Y}=\mathrm{b} 0+\mathrm{b} 1 \mathrm{X} 1+\mathrm{b} 2 \mathrm{X} 2+\ldots+\mathrm{bnXn}$, where}

Y-level of investment attractiveness of the region; b0, b1, b2...bn -criteria for assessing the investment attractiveness of the region; $\mathrm{X} 1, \mathrm{X} 2, \mathrm{X} 3 \ldots \mathrm{Xn}$ - weight of the criteria.

Using this method, experts can assign weights to criteria based on the specifics of territorial entities, which will reveal a real assessment of the level of investment attractiveness of the region. "Investors will be able to specifically identify regions that are favorable for investment, and the regional leadership will be able to identify weaknesses and take measures to improve investment attractiveness and stimulate investment activity".

Each region is evaluated annually depending on the level of attractiveness, to determine the rating of regions [13].
A set of indicators from the list was used to calculate the rating. In the process of allocating regions to rating groups, cluster analysis was used to make the final distribution of regions objective and less dependent on expert judgments. Statistical indicators are used to assess the investment attractiveness of regions. The source of these indicators is official publications of statistical agencies, as well as the Bank of Russia, the Ministry of Finance, the Ministry of economic development, the Ministry of communications and mass media, and the Ministry of natural resources and ecology.

To assess not only quantitative, but also qualitative indicators of factors of investment attractiveness of the region, the method of expert assessment of the attractiveness of the region is applied. This method assumes that expert judgments are determined by analysts of research and educational centers and independent experts using a standardized point scale.

\section{MAIN PART}

Spatial differentiation of investment attractiveness of the region, represents promising points of growth of specialization of the region, with the establishment of the main territorial aspects of development. Each growth point can identify the prerequisites for accelerating the economic development of the region and form regional network structures.

In the regions of Russia, active growth points that are promising for investment are: data collection, processing, and systematization, as well as data Analytics systems. There is a huge market with a large amount of work associated with digitizing the space in which a person lives. This is the level of the house, the level of the settlement, the infrastructure and interaction of all these objects within the Internet of things. This is the biggest growth point in the near horizon. This includes urban planning at a new level, and a new level of exploitation of all places of human life. New technologies and materials for their construction are also becoming interesting for investors, which is due to the high growth rates of housing, civil and industrial construction. Logistics development, transport interchanges that allow faster and cheaper transfer of the produced product, optimization of the supply of resources.

The spatial differentiation of investment attractiveness of regions is clearly shown in figure 1 . The indicator of investment in fixed assets for the subjects of the Russian Federation is very important, since it stimulates business development and leads to an increase in the profit received. The amount of funds invested can strengthen the level and growth rate of the region and strengthen the country's economy as a whole.

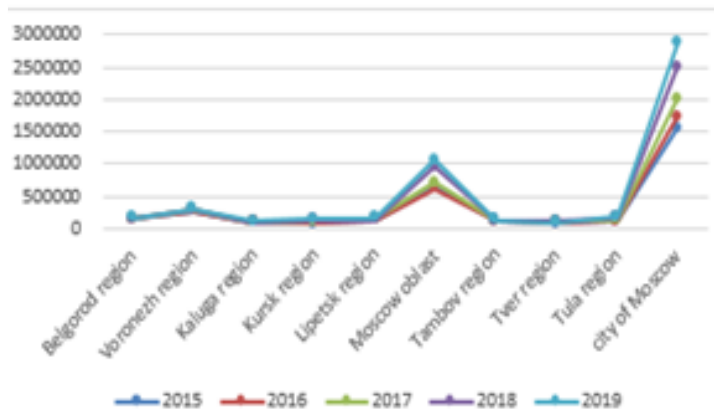

Fig.1. Investment in fixed assets by subjects of the Russian Federation

Cyclical improvement of socio-economic indicators in the leading regions is achieved due to the fact that the available resource potential creates economic and investment activity, 
which, in turn, increases the level of development of the region and its attractiveness to investors.

According to the" strategy of spatial development of the Russian Federation for the period up to 2025 " [11], reducing the level of spatial diversification of regions is one of the priorities of the Russian Federation. "Reduction of the level of interregional differentiation in the socio-economic development of regions, reduction of intra-regional differences in the economy of regions" [9].

The strategy involves the introduction of new spatial differentiation targets, such as the human development index. A positive scenario assumes that this index will reach $101 \%$ by 2025 , which in turn will contribute to the development of the territory and reduce spatial differentiation.

Analyse the data, we see that the city of Moscow remains the driver of the Russian economy - more than 2 trillion rubles were invested in the city's economy in 2019 , which is $20 \%$ more than a year earlier. Or $13 \%$ of all Russian investments. Moreover, the growth rate of $20 \%$ has been maintained for the third year in a row. For comparison, in 2015, it accounted for only 9.4 per cent. In just 4 years, the volume of investments in the capital's economy has grown almost 2 times.

The second place is occupied by the Moscow region, where the concentration of large businesses is also high. It has become a record holder in terms of investment growth: the volume of investments increased almost 1.5 times last year.

Saint Petersburg showed the same pace, but the volume of investments there has never decreased over the past 4 years: last year it amounted to more than 600 billion rubles.

The Krasnodar territory, Belgorod region, and Voronezh region are actively gaining momentum in regional development, taking high places in investment attractiveness ratings and identifying new promising investment areas.

The assessment of the level of spatial differentiation of investment attractiveness of regions is based on the criteria presented in figure 2 .

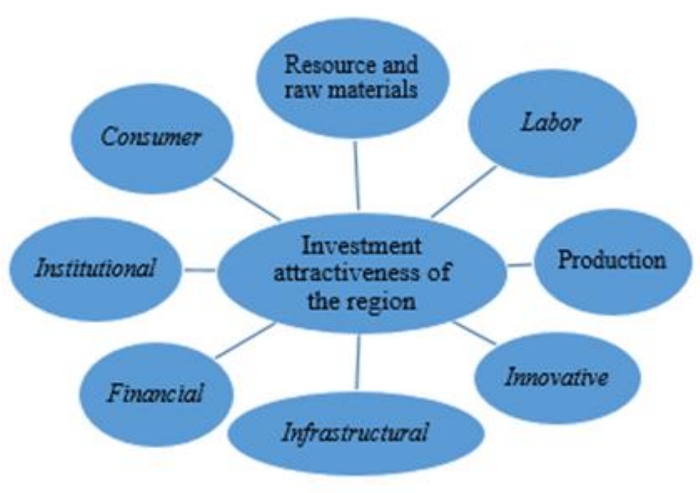

Fig.2. Criteria for assessing the level of investment attractiveness of regions

In addition to the qualitative criteria evaluated by the expert group, quantitative criteria are important for forming the investment attractiveness of the region, since their analysis allows us to obtain specific numerical values that investors can use when making a choice about the investment object. Quantitative indicators are presented in statistical data for the region and are publicly available to investors. Experts classify these indicators for assessing the investment attractiveness of the region by their level of significance.
Qualitative criteria influencing the formation of investment attractiveness of the region, include: the image of the territory and the country as a whole; the well developed investment legislation; the stability of the state structure; the quality and transparency for investors investment policy of administration of Subject of Federation, etc. Quality criteria are evaluated using an expert approach

Expert evaluation of the criteria is carried out on a 9-point scale. Points from 1 to 3 indicate a low degree of influence of the criterion on the investment attractiveness of the region; points from 4-6 indicate an average level of influence on the investment attractiveness of the region, points from 7-9 indicate a high level of influence of this criterion on the investment attractiveness of the region.

Let's look at the top 10 Russian regions in terms of investment attractiveness in 2020 (table 1).

TABEL I. INVESTMENT ATTRACTIVENESS OF RUSSIAN REGIONS TOP-10 IN 2020

\begin{tabular}{|c|c|c|c|c|}
\hline № & Subject Of The Russian Federation & 2020 & 2019 & Comparison of positions \\
\hline 1 & Moscow & 1 & 1 & 0 \\
\hline 2 & Moscow oblast & 2 & 2 & 0 \\
\hline 3 & Saint-Petersburg & 3 & 6 & +3 \\
\hline 4 & Republic of Tatarstan & 4 & 5 & +1 \\
\hline 5 & Tula region & 5 & 7 & +2 \\
\hline 6 & Krasnodar region & 6 & 13 & +7 \\
\hline 7 & Belgorod region & 7 & 8 & +1 \\
\hline 8 & Kaluga region & 8 & 4 & -4 \\
\hline 9 & Republic of Bashkortostan & 9 & 16 & +7 \\
\hline 10 & Yaroslavl region & 10 & 18 & +8 \\
\hline
\end{tabular}

Increasing the investment attractiveness of regions is due to state support, distribution of funds between industry structures, and the formation of new logistics networks. The subjects of the Russian Federation take stimulating measures in the form of subsidies and grants for promising areas of regional development. Attracting investors, creating "investment platforms". One of the important aspects is the reduction of administrative barriers and optimization of registration procedures, the introduction of preferential taxation. Attracting foreign investment plays an important role for the regions. At the moment, one of the active investors is China, Germany, Italy, the USA, etc.

The investment attractiveness of regions depends largely on the availability of cheap energy resources, the natural climate, staffing, the production state of fixed assets, and other factors.

This article suggests that when assessing the investment attractiveness of the region, take into account a new criterion, namely, the presence of research and educational centers (RECs) in the region. In the Russian Federation, within the framework of the national project "Science", world-class scientific and educational centers were formed.

In 2020, more than 15 regions have research and education centers or have applied to open a world-class research and education center.

The directions of scientific innovation activity of these centers directly depend on the priority areas of development of the region: creation of a network of advanced infrastructure for innovative activities in the field of agriculture, development of the personnel potential of the agricultural and industrial complex, oil and gas industry, nuclear medicine, etc.

One of the most promising scientific and educational centers is "Innovations in agriculture", Belgorod region. This center is organized on the basis of the Belgorod state national research University. 
Agriculture has historically been the most important economic activity in the Belgorod region. About $77 \%$ of the region's land area is black earth. Thus, the region accounts for $13.7 \%$ of all-Russian soybean production, $6.4 \%$ of sugar beet, $3.2 \%$ of sunflower, $3 \%$ of grain, $2 \%$ of potatoes, $1.9 \%$ of vegetables. In terms of grain production per inhabitant, the Belgorod region is 2.8 times ahead of the national average.

The volume of exports of agricultural products in the region has increased by 2.5 times since 2015 and by 2018 it was $\$ 353.3$ million, or more than $1.5 \%$ of the national total indicator's.

As exporters in the markets of 82 countries of the world 71 Belgorod enterprises are certified the company, of which 30 Belgorod manufacturers supply their own products to 24 countries, including 22 China, USA, Sweden, Israel, Oman, Netherlands and others.

The center has five platforms: biotechnology; cell technologies and genetic engineering in crop production; cell technologies and genetic engineering in animal husbandry; health-saving technologies; and environmental management.

The development of a world-class scientific and educational center in the Belgorod region will greatly contribute to the development of "smart" agricultural production within the center, aimed at the effective use of the latest technological achievements in the field of information and communication technologies, the formation of production chains that go beyond a single enterprise, and the creation of so-called cyber-physical systems/interconnected complexes.

The functioning of research and education centers is carried out in the form of public-private partnership. This type of partnership is one of the most important investment mechanisms that determines the state's need to implement a variety of activities with a limited amount of available resources.

Attracting private investment to the region can contribute to the development of a number of areas with greater efficiency. At the same time, an additional effect is achieved in terms of combining the resources of the state and business, when each of the participants makes the best use of the resources available to them, including project management experience. As a result, not only a mechanism for achieving socially significant interests with the most efficient use of resources available to the state is formed, but also a specific mechanism for attracting investment.

The mechanism of public private partnership is proposed in figure 3. This mechanism involves increasing the level of investment attractiveness of regions through the introduction of innovative solutions and opportunities.

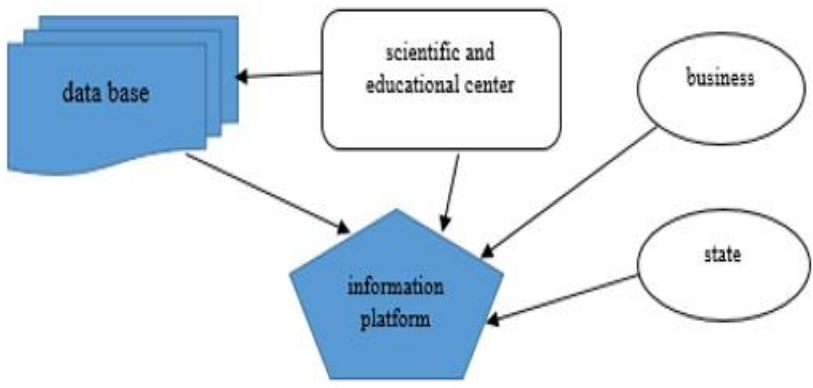

Fig.3. Public private partnership mechanism

The mechanism of public private partnership assumes that in order to reduce the spatial differentiation of investment attractiveness of regions, it is necessary to create a unified database of investment opportunities in the regions, indicating
Federal and regional support tools and mechanisms, as well as information about promising enterprises.

This database should include all sectors and branches of the economy of the Russian Federation.

Creating a database of planned, implemented and completed projects will help you effectively monitor the implementation of investment projects. The expert community, based on the experience of past projects, will be able to anticipate the consequences of implementation and correct the project in a timely manner.

Each region should have information about possible sources of funding. This information should be freely available to both the authorities and the business community.

All these measures are possible with the interaction of the state, business structures and the scientific community, within the framework of world-class scientific and educational centers.

\section{CONCLUSION}

Based on the data of the investment attractiveness rating of the Russian regions for 2020, it is safe to say that the key to the first places in the rating are good business conditions, natural resources and capital advantages. Moscow is still at the top of the list. Regions with developing resource potential are gradually becoming leaders. An important condition for investment success is also the comfort of providing institutional services, as proved by the Belgorod and Kaluga regions.

The introduction of the criterion for the availability of research and educational centers will allow us to characterize the region as effectively developing, able to offer high-quality personnel and scientific support, promising investment areas. This will not only increase the level of investment attractiveness of the region, but also identify possible growth points for investors.

\section{ACKNOWLEDGMENT}

The research was carried out within the framework of the state assignment of NRU BelSU FZWG-2020-0016 (0624-2020-0016), the topic of the project "Fundamental foundations of global territorial and industry specialization in the context of digitalization and technology convergence".

\section{REFERENCES}

[1] A. G. Granberg, "Modeling of spatial development of national and world economy: evolution of approaches", Region: Economics and Sociology, 2007, pp. 87-107.

[2] G. A. Aleksandrov., I. V Vyakina., E. V. Pavlova., G. G. Skvortsova O. A. Kondrat'eva, Rusin the attractiveness of the investment climate and investment risks: methodology, diagnostic methods and evaluation. Moscow, 2020. - 340 p. - ISBN: 978-5-91292-305-0 DOI: $10.18334 / 9785912923050$

[3] L.S. Arkhipova, G.Y. Gagarina, Spatial differentiation of regions of the Russian Federation and their competitiveness, Bulletin of the Udmurt University. Series "Economics and law", 2015. URL: https://cyberleninka.ru/article/n/prostranstvennaya-differentsiatsiyaregionov-rf-i-ih-konkurentosposobnost /(accessed 18.10.2020).

[4] G. A., Aleksandrov, I. V. Vyakina, "On the need to develop the methodology for evaluating the effectiveness of investments", Russian entrepreneurship, 2018, 19, 1, pp. 195-206. DOI: 10.18334/rp.19.1.38697.URL:https://elibrary.ru/item.asp?id=3248372 7! (accessed 18.10.2020).

[5] V. V. Litvinova, Investment attractiveness and investment climate of the region: monograph, Moscow: Financial University, 2013, $116 \mathrm{p}$.

[6] S. Altug, F.S. Demers, M. Demers, "The investment tax credit and irreversible investment",Journal of Macroeconomics, 2009, 31, 4, pp. 509-522.URL:https://doi.org/10.1016/j.jmacro.2009.01.001/(accessed 18.10.2020). 
[7] D. Barbosa, V.M. Carvalho, P.J. Pereira, "Public stimulus for private investment: An extended real options model. Economic Modelling",
2016 ,
vol.
5 ,
pp.
$742-748$.

URL:https://doi.org/10.1016/j.econmod.2015.10.013/(accessed

18.10.2020).

[8] A. M. Ajlouni, A. I. Solodovnik, Public-private partnership: state and prospects in the modern Russian economy, Moscow economic journal, 2017, 3, URL: http://qje.su/otraslevaya-i-regionalnayaekonomika/moskovskij-ekonomicheskij-zhurnal-3-2017-53/(accessed 18.10.2020).

[9] E. S. Savchenko, O.A. Pavlova., Zhuravleva Scientific-educational center of world-class "Innovative solutions in agriculture" as a driver of development of regional economics", science and technology of APC, 2020, 9. URL: https://cyberleninka.ru/article/n/nauchnoobrazovatelnyy-tsentr-mirovogo-urovnya-innovatsionnye-resheniyav-apk-kak-drayver-razvitiya-regionalnoy-ekonomiki/_accessed 18.10.2020).

[10] I. V. Vyakina, Spatial differentiation of investment attractiveness of regions in the context of economic security, Economic analysis: theory $\begin{array}{lllll}\text { and practice, } & 2017, & 8 & \text { (467). } & \text { URL: }\end{array}$ https://cyberleninka.ru/article/n/prostranstvennaya-differentsiatsiyainvestitsionnoy-privlekatelnosti-regionov-v-kontekste-obespecheniyaekonomicheskoy/(accessed 04.11.2020).

[11] S. Bose, S.K. Roy, A.K. Tiwari, "Measuring customer-based place brand equity (CBPBE): An investment attractiveness perspective". Journal of Strategic Marketing, 2016, 24(7), pp.617-634.

[12] A. E. Kremin and I. G. Akhmetova, "Problems of assessing the investment attractiveness of the region's territory". In Proceedings of the III International Scientific and Practical Conference (DEFIN '20). Association for Computing Machinery, New York, NY, USA, Article 46, -2020. pp.1-5. DOI:https://doi.org/10.1145/3388984.3390816

[13] I. V. Vyakina, "Economic security of doing business in Russia and mechanisms of protection of entrepreneurs' rights", Revista ESPACIOS, 2019, 40 (Number 14), p. 20 URL: https://elibrary.ru/item.asp?id=37714227 and URL: http://www. revistaespacios. com/a19v40n14/19401420.html/(accessed 18.10.2020). 